\title{
Self-reported periodontitis in cannabis club members in Montevideo, Uruguay. An exploratory study
}

\author{
Sebastián Perez-Rivoir', Magdalena Mayol', Ernesto Andrade', Luis A. Bueno-Rossy?', \\ Cassiano K. Rösing ${ }^{2}$
}

1. Universidad de la República, Facultad de Odontología, Cátedra de Periodoncia, Montevideo, Uruguay

2. Universidade Federal do Rio Grande do Sul, Facultade de Odontologia, Departamento de Odontología

Conservadora, Rio Grande do Sul, Brasil

\begin{abstract}
In 2013, the Oriental Republic of Uruguay enacted a law regulating the cannabis market, and since then, an increasing number of users has been registered. Previous reports based on data from other countries link cannabis smokers to worse periodontal health status. The aim of this study is to describe self-reported gingival and periodontal health status and estimate the prevalence of periodontitis among Uruguayan cannabis club members. A cross-sectional study was conducted on a convenience sample of cannabis club members in Uruguay. A survey was used to gather sociodemographic data and information on oral hygiene, use of cannabis and other drugs, and self-reported gingival and periodontal health status. Eight questions validated in Spanish were used to estimate the
\end{abstract}

prevalence of total periodontitis and severe periodontitis, based on two previously implemented predictive models. The survey was completed by 50 people, of whom $68 \%$ were male and $78 \%$ were in the 20-40 year age range. Based on the first model, estimated prevalence was $12 \%$ for total periodontitis and $10 \%$ for severe periodontitis. Based on the second model, estimated prevalence was $36 \%$ for total periodontitis and $12 \%$ for severe periodontitis. These findings suggest that smoking cannabis could potentially have a detrimental effect on oral health status. Received: May 2021; Accepted: October 2021.

Keywords: cannabis - periodontitis - epidemiology - marijuana abuse.

\section{Periodontitis auto-reportada en miembros de clubes de cannabis en Montevideo, Uruguay. Estudio exploratorio}

\begin{abstract}
RESUMEN
En 2013 se aprobó la ley que regula el mercado del cannabis en la República Oriental del Uruguay y desde entonces se ha registrado un creciente número de consumidores. Reportes previos a partir de datos de otros países vinculan un peor estado de salud periodontal en fumadores de cannabis. El objetivo de este estudio es describir el estado gingivo-periodontal auto-reportado y estimar la prevalencia de periodontitis en participantes de clubes cannábicos uruguayos. Se realizó un estudio transversal a partir de una muestra por conveniencia de integrantes de clubes cannábicos en Uruguay. Mediante una encuesta se recolectaron datos socio-demográficos, de higiene oral, de consumo de cannabis y otras drogas, así como de auto-reporte del estado de salud gingivo-periodontal. A partir de 8 preguntas
\end{abstract}

\section{INTRODUCTION}

In December 2013, the Oriental Republic of Uruguay enacted law 19.172 establishing a regulatory framework for the cannabis market. The Institute for Regulation and Control of Cannabis (Instituto de Regulación y Control del Cannabis, IRCCA) was validadas en español se estimó la prevalencia de periodontitis total y severa a través de dos modelos predictivos previamente implementados. Un total de 50 personas completaron la encuesta. El $68 \%$ eran hombres y el $78 \%$ estaba dentro del rango de 20 a 40 años de edad. Con el primer modelo la prevalencia estimada de periodontitis total fue $12 \%$ y de periodontitis severa $10 \%$. Con el segundo modelo fue $36 \%$ para periodontitis total y $12 \%$ para periodontitis severa. Estos hallazgos sugieren que fumar cannabis podría tener un potencial efecto deletéreo sobre las condiciones de salud bucal.

Palabras clave: canabis - periodontitis - epidemiología - abuso de marihuana.

created to regulate plantation, cultivation, harvest, production, processing, stocking, distribution and sale of cannabis, and to promote actions to reduce the risks and damage associated to the problematic use of cannabis ${ }^{1}$. In June 2018, 35.246 people were 
registered for regulated access to marijuana, of whom 2.339 figured as members of 91 cannabis clubs ${ }^{2}$. Data for frequency of marijuana consumption in Uruguay according to age range show that approximately one out of every five persons between the ages of 26 and 35 years uses it daily, with this age range having the highest consumption. In addition, it was found that out of every 100 persons who had tried marijuana, 7 showed problematic use of the substance ${ }^{3}$.

Xerostomia is one of the adverse effects observed in the oral cavity associated to cannabis consumption ${ }^{4}$. This condition is related to difficulties in adequate control of biofilm and to increased gingival inflammation ${ }^{5}$. Moreover, gingivitis and periodontal diseases are among the most prevalent diseases in in the world. World prevalence of total periodontitis has been reported as $5 \%$ to $70 \%$, with differences among age ranges ${ }^{6}$. Moreover, it has been reported that approximately $11 \%$ of the population has severe periodontitis ${ }^{7}$. Risk factors for periodontitis, such as smoking and diabetes mellitus, have been extensively studied ${ }^{8}$, as have environmental and behavioral factors, and certain microbiological aspects.

Self-reporting of different medical conditions such as diabetes, hypertension or myocardial infarction has been used for several years as a basis on which to monitor health status and trends over time in populations. In 2003, in the USA, self-reported evaluation was promoted as an alternative measure for surveillance of periodontal disease, since clinical examination requires great use of resources, both human and logistic, substantially increasing costs 9 .

Later, in 2007, results of the Australian National Survey of Adult Oral Health ${ }^{10}$ were published. This survey included 11 questions (6 gingivitis and periodontal disease screening questions and 5 conventional risk indicators) in large population surveys, yielding useful levels of validity in predicting moderate/severe to severe periodontitis.

A joint study by the Centers for Disease Control and Prevention (CDC) and the American Academy of Periodontology (AAP) ${ }^{11}$ proposed to use eight questions in English and Spanish, which were subsequently assessed for validation in populations in the USA (including Spanish speakers) ${ }^{12}$. The use of this tool was studied further in Brazil, as part of a questionnaire consisting of 18 questions ${ }^{13}$, and in France, where an additional four questions were included ${ }^{14}$. Validation in Spanish was performed in
Spain, both in Madrid ${ }^{15}$ and in Barcelona ${ }^{16}$, where a set of 12 questions, including the 8 mentioned above ${ }^{11}$, was used.

Verhulst et $\mathrm{a} 1^{17}$ applied the questionnaire created by Eke and Genco $^{10}$ at the Academic Centre for Dentistry, Amsterdam (ACTA, by its acronym in Dutch), based on which they proposed 3 models for predicting total periodontitis and severe periodontitis. Model 1 uses self-reported answers on periodontal disease, demographic data and oral biomarker values, model 2 uses self-reported answers and demographic data, and model 3 uses only self-reported answers on periodontal disease. The authors found that model 3 provides acceptable values for predicting periodontitis.

A systematic review with meta-analysis published in $2016^{18}$ shows that in general, self-reporting is useful for identifying presence of periodontitis. The sensitivity values for most of the questions were lower than the specificity values, therefore these questions are better at identifying people who do not have periodontitis.

Several epidemiological studies have addressed gingival and periodontal health status in cannabis smokers ${ }^{19-22}$, finding a positive association between smoking cannabis and periodontal health status. A recent systematic review ${ }^{23}$ of a wide range of studies suggests this association may be dose-dependent, and recommends further studies with longer followup times and control for risk factors/indicators such as tobacco, diabetes and age. It also recommends reporting how long the substance has been used, use frequency, and substance composition and quantity. Thus, exploratory studies are still required to further address the issue of association between marijuana consumption and periodontal diseases.

The aims of this exploratory study are therefore to describe self-reported gingival-periodontal status and to estimate the prevalence of periodontitis based on a predictive model among members of cannabis clubs in Montevideo, Uruguay.

\section{MATERIALS AND METHODS}

A cross-sectional study was performed from July to October 2018, based on a convenience sample of cannabis club members in Uruguay. This survey was approved by the Ethics Committee at the School of Dentistry, University of the Republic (Uruguay).

In June 2018, there were 109 clubs with membership registered at the IRCCA, representing 2339 persons 
over 18 years of age. Fifty percent of these clubs were in Montevideo. Invitations to participate in the survey were extended through the president of the IRCCA, who informed the directors of the cannabis clubs via email, asking them to send club members the invitation to participate in the survey. People who expressed interest in taking part in the study were contacted by the research team to provide further information on the study and arrange a meeting for interviews. When there was no answer, invitations were sent for a second time after two months.

After reading and signing informed consent, each subject completed a voluntary, self-administered survey containing multiple-choice questions. With guidance from two researchers (SP and $\mathrm{MM}$ ), questions were asked about identity data, sociodemographic characteristics, and profile regarding consumption of cannabis, alcohol and other drugs.

Self-reported gingival-periodontal health status was evaluated based on the Spanish version of a set of questions suggested by Eke and Genco ${ }^{11}$ (Q1-Q8). Before beginning this study, the questions were assessed for clarity, ease of understanding and cultural adaptation by testing them on 20 patients at the Periodontics Clinic at the School of Dentistry, University of the Republic. Finally, the data collected in the surveys were entered in spreadsheets for subsequent analysis. Total exposure to tobacco was calculated in "pack years" for current smokers, following Susin et $\mathrm{al}^{24}$, forming 3 groups: Light (1 to 2734 packs), Moderate (2735 to 7300 packs) and Heavy (more than 7300 packs). Mean age \pm standard deviation (SD) was calculated. Prevalence was estimated for total periodontitis (TP) and severe periodontitis (SP), based on two predictive models (models 2 and 3) proposed by Verhulst et al ${ }^{17}$. For total periodontitis, model 2 employs the data from questions Q2, Q3, Q4, Q8 and age, while model 3 includes data from questions Q2, Q3, Q4 and Q8. For severe periodontitis, model 2 employs data from questions Q2, Q3, Q4, Q8, age and sex, while model 3 uses questions Q2, Q3, Q4 and Q8.

\section{RESULTS}

A total 56 members of five cannabis clubs agreed to answer the questionnaire. Of these, 50 completed the survey and 6 decided not to participate due to lack of time. Table 1 provides respondent demographics, showing that the proportion of males was higher than
Table 1. Participant demographics. Montevideo, 2018

\begin{tabular}{|c|c|c|c|}
\hline \\
\hline & & $\mathbf{n}$ & $\%$ \\
\hline \multirow{3}{*}{ Sex } & Female & 11 & 22 \\
\hline & Male & 34 & 68 \\
\hline & Not reported & 5 & 10 \\
\hline \multirow{4}{*}{ Age } & $20-30$ & 20 & 40 \\
\hline & $31-40$ & 19 & 38 \\
\hline & $41-50$ & 7 & 14 \\
\hline & Not reported & 4 & 8 \\
\hline \multirow{4}{*}{ Education level } & Primary & 0 & 0 \\
\hline & Secondary & 15 & 30 \\
\hline & Tertiary & 30 & 60 \\
\hline & Not reported & 5 & 10 \\
\hline \multirow{4}{*}{ Occupation } & $\begin{array}{l}\text { Employed (public } \\
\text { or private)/ self- } \\
\text { employed }\end{array}$ & 38 & 76 \\
\hline & Student & 5 & 10 \\
\hline & Unemployed & 2 & 4 \\
\hline & Not reported & 5 & 10 \\
\hline \multirow{2}{*}{$\begin{array}{l}\text { Toothbrushing } \\
\text { frequency }\end{array}$} & $\leq 1 /$ day & 5 & 10 \\
\hline & $\geq 2 /$ day & 45 & 90 \\
\hline
\end{tabular}

females (68\% vs. $22 \%$ ), $60 \%$ had university-level studies, and $76 \%$ were employed or self-employed. It shows that the population is young, with mean age $32( \pm 7.8)$ years, with the age range 20 to 40 years making up $78 \%$ of the total.

For toothbrushing frequency, $90 \%$ of the respondents reported brushing their teeth twice a day or more, while $10 \%$ reported doing so only once a day or less. Regarding tobacco use (Table 2), the number of smokers was equal to the number of former smokers and similar to the number of people who had not smoked tobacco previously. Table 2 also shows the characteristics of tobacco consumption and the number of "pack years" 24 for respondents who

\section{Table 2. Participant tobacco use profile. Montevideo, 2018}

\begin{tabular}{|c|c|c|c|}
\hline \multirow{3}{*}{ Smoking habits } & Smoker & 17 & 34 \\
\hline & Ex-smoker & 17 & 34 \\
\hline & Never smoked & 15 & 30 \\
\hline \multirow{2}{*}{ Pack years } & Not reported & 1 & 2 \\
\hline & Light & 10 & 59 \\
\hline & Moderate & 5 & 29 \\
\hline
\end{tabular}


agreed to report how long they had been smokers and how much they consumed, of whom 10 were light, 5 moderate and 2 heavy smokers.

Table 3 shows consumption of alcohol and other drugs. Most respondents reported consuming alcohol one to four times a week (62\%). In addition, 21 respondents reported using other recreational drugs (e.g., cocaine, designer drugs or others), of whom 12 declined to provide frequency of use.

Table 3. Participant non-cannabis drug use profile. Montevideo, 2018

\section{Frequency of use} during the past year

$5-7$

$1-4$

Alcohol

$<1$

No use

Declines to answer

Type

Cocaine, designer drugs, others

None

Recreational drugs

\begin{tabular}{|c|c|c|}
\hline $\begin{array}{c}\text { Declines to answer } \\
\text { Frequency }\end{array}$ & 19 & 38 \\
\hline Daily & 1 & 5 \\
\hline$<1 /$ week & 8 & 38 \\
\hline Declines to answer & 12 & 57 \\
\hline
\end{tabular}

Table 4. Participant cannabis use profile. Montevideo, 2018

\begin{tabular}{|c|c|c|c|}
\hline Weekly frequency & $4-6$ & 9 & 18 \\
\hline \multirow{3}{*}{ Grams per month } & $1-3$ & 6 & 12 \\
\hline & $>41$ & 3 & 6 \\
\hline $\begin{array}{c}\text { Cannabis use (not } \\
\text { smoked) }\end{array}$ & Yes & 22 & 44 \\
\hline & No & 25 & 50 \\
\hline & $\begin{array}{c}\text { Declines to } \\
\text { answer }\end{array}$ & 1 & 44 \\
\hline
\end{tabular}

Years of use

$16-20$

Table 4 shows time and frequency of cannabis use, showing that $56 \%$ had smoked cannabis for more than 10 years and $70 \%$ did so daily. Half the sample reported using less than $20 \mathrm{~g}$ per month, with the other half reporting more than $20 \mathrm{~g}$ per month, among whom 6 persons used more than $40 \mathrm{~g}$ per month.

Evaluation of the 8 specific questions on selfreported periodontal disease (Table 5) found that

\section{Table 5. Participant self-reported periodontal} disease.

Montevideo, 2018

$$
\begin{aligned}
& \text { Q1 - Do you think you } \\
& \text { might have gum dis- } \\
& \text { ease? } \\
& \text { Q2 - In general, how } \\
& \text { would you describe the } \\
& \text { health status of your } \\
& \text { teeth and gums? }
\end{aligned}
$$

Q3 - Have you ever had ever gum treatment such as root scaling or planing, sometimes known as "deep cleaning"?

Q4 - Have you ever had a tooth that became loose on its own without having had a lesion?

Q5 - Has a dental professional ever told you but you have lost bone around your teeth?

Q6 - In the last 3

months, have you noticed at tooth that does not seem to look good?

Q7 - Apart from toothbrushing, during the last seven days, how many times have you used dental floss or some other tool for cleaning between your teeth? (number of days)

Q8 - Apart from tooth-

\begin{tabular}{|c|c|c|}
\hline & $n$ & $\%$ \\
\hline Yes & 10 & 20 \\
\hline No & 39 & 78 \\
\hline $\begin{array}{l}\text { Don't know/ } \\
\text { Don't answer }\end{array}$ & 1 & 2 \\
\hline Excellent & 4 & 8 \\
\hline Very good & 9 & 18 \\
\hline Good & 16 & 32 \\
\hline Regular & 17 & 34 \\
\hline Bad & 3 & 6 \\
\hline $\begin{array}{l}\text { Don't know/ } \\
\text { Don't answer }\end{array}$ & 1 & 2 \\
\hline Yes & 8 & 16 \\
\hline No & 41 & 82 \\
\hline $\begin{array}{l}\text { Don't know/ } \\
\text { Don't answer }\end{array}$ & 1 & 2 \\
\hline Yes & 9 & 18 \\
\hline No & 40 & 80 \\
\hline $\begin{array}{l}\text { Don't know/ } \\
\text { Don't answer }\end{array}$ & 1 & 2 \\
\hline Yes & 5 & 10 \\
\hline No & 44 & 88 \\
\hline $\begin{array}{l}\text { Don't know/ } \\
\text { Don't answer }\end{array}$ & 1 & 2 \\
\hline Yes & 14 & 28 \\
\hline No & 35 & 70 \\
\hline $\begin{array}{l}\text { Don't know/ } \\
\text { Don't answer }\end{array}$ & 1 & 2 \\
\hline $1-2$ & 15 & 30 \\
\hline $3-4$ & 9 & 18 \\
\hline $5-6$ & 3 & 6 \\
\hline $7+$ & 15 & 30 \\
\hline Never & 7 & 14 \\
\hline Not reported & 1 & 2 \\
\hline $1-3$ & 12 & 24 \\
\hline $4-6$ & 6 & 12 \\
\hline $7+$ & 10 & 20 \\
\hline Never & 19 & 38 \\
\hline Not reported & 3 & 6 \\
\hline
\end{tabular}
brushing, during the last seven days how many times have you used a mouthwash or other treatment for tooth diseases or problems? 
only one person did not answer any of the questions, so that the answer rate was $98 \%$ for all questions. Table 6 shows prevalence of total periodontitis (TP) and severe periodontitis (SP). With model 2, prevalence of total periodontitis was $12 \%$ (6 cases) and prevalence of severe periodontitis was $10 \%(5$ cases), while with model 3 , the values were higher, TP $36 \%$ and SP $10 \%$.

\section{Table 6. Prevalence of total periodontitis and severe periodontitis

\begin{tabular}{|c|c|c|c|} 
& & $\mathbf{n}$ & $\%(\mathbf{C l}: 95 \%)$ \\
\hline \multirow{2}{*}{ Model 2} & Total periodontitis & 6 & $12,2(3.0-21.4)$ \\
\cline { 2 - 4 } Model 3 & Severe periodontitis & 5 & $10.2(1.7-18.6)$ \\
\cline { 2 - 4 } & Total periodontitis & 18 & $36.7(23.2-50.2)$ \\
\hline \multirow{2}{*}{ Severe periodontitis } & 5 & $10.2(1.7-18.6)$
\end{tabular}

\section{DISCUSSION}

This study evaluated self-reported periodontitis among recreational cannabis users who were members of cannabis clubs in Montevideo, Uruguay. This study has no parallel in the literature because it was conducted in Uruguay, which regulates recreational cannabis use, allowing distribution and/or sale of cannabis in pharmacies, home cultivation and the so-called cannabis clubs. These clubs are associations that gather cannabis users and are located throughout the country. The clubs are registered at the IRCCA, a public, governmentsponsored legal entity. The current study is one of the first to focus on cannabis club members with the aim of learning about situations of disease, and the first to address periodontal health issues. Possibly as a result of this, plus mistrust regarding the use of data, there were difficulties in collecting data.

Given the confidentiality required for the study, the sampling process was administered by the IRCCA, which sent the consent forms and the survey to the coordinators of each club. The coordinators sent the forms to club members, although some of them prevented the process from continuing. The response rate from clubs was very low - less than 5\%. Questionnaires were applied to a total 56 Uruguayan cannabis club members. Thus, this study does not intend to claim external validity, but provides a first exploratory study in order to propose future research hypotheses so that, over time and when the use policy matures, other studies may be conducted with higher response rates.
Due to the peculiarity of the sample, it is not currently possible to achieve greater approximations by means of, e.g., clinical examinations or other additional parameters. This study used self-reported results for periodontitis provided by cannabis club members, as well as their sociodemographic characteristics, hygiene habits, and associated addictions, among other factors. Self-reported periodontitis was evaluated through the Spanish language version of the questions developed by Eke and Genco ${ }^{11}$.

Six of the subjects declined to respond to the questionnaire, alleging lack of time to answer. Therefore, although there is not a response rate for the total sample, about $10 \%$ did not respond effectively, a rate similar to those reported in previous studies such as Eke et $\mathrm{al}^{25}$.

The subjects who participated in this study were mainly male $(68 \%)$, mostly in the age range 20 to 40 years $(78 \%)$, and more than half had reached university-level studies. These situations are in line with the distribution data for recreational cannabis users $^{3}$. In terms of occupation, distribution was similar to that of the general population, so it may be inferred that the study sample is very similar to the universe of cannabis users in Uruguay.

This study considered additional use of other illegal drugs which are often associated with recreational use of cannabis ${ }^{26}$. Prevalence of use of illegal drugs such as cocaine or other synthetic drugs was $42 \%$ of the sample. It is worth highlighting that, given the peculiarity of the question, $38 \%$ of the participants declined to answer, with an even higher percentage not answering the question about frequency of use of other drugs.

Ninety percent of the sample had consumed alcohol during the past year, which is higher than the percentage recorded in the country in previous years $(71.1 \%)^{3}$. In turn, $62 \%$ of the sample reported consuming alcohol 1 to 4 times a week, which was also higher than previous data for the country ${ }^{3}$. With regard to smoking, one third of the sample were current smokers, which is similar to national data. However, frequency of tobacco consumption was lower than observed in the general population ${ }^{3}$.

The pattern of cannabis use shows that most respondents had been using it for over 10 years. This is considered long-term exposure., i.e., they were not occasional users or short-term users, so it may be inferred that at the time of reporting, any damage could already be detected. One of the 
important features of this study is that, in contrast to the occasional exposures reported in another study ${ }^{27}$, it evaluates frequent and regular cannabis users, since most of them consumed it on a daily basis and in considerable amounts per month, with $50 \%$ consuming more than $20 \mathrm{~g}$ per month. It is important to highlight that the values recorded for prevalence as well as frequency of use (daily and over the past 12 months) in cannabis users in Uruguay has increased relative to surveys conducted in $2016^{3}$ and $2007^{28}$, with highest prevalence of use among men aged 18 to 34 years, with similar sociodemographic characteristics.

In the current study, theresults for estimated prevalence of self-reported periodontitis differed according to the model applied, particularly for total periodontitis, which was $12.2 \%$ in model 2 versus $36.7 \%$ in model 3 . In contrast, both models found the same percentage $(10.2 \%)$ for severe periodontitis. This may be explained by the characteristics of this convenience sample, where there is predominance of male sex and persons younger than 40 years, which are variables that are employed in model 2 proposed by Verhulst et $\mathrm{a}^{17}$. These data are similar to the distribution found for Uruguay's adult population in its 2015 National Oral Health Survey ${ }^{29}$, although it is interesting to note the difference in terms of age ranges, because

\section{DECLARATION OF CONFLICTING INTERESTS}

The authors declare no potential conflicts of interest regarding the research, authorship, and/or publication of this article.

\section{FUNDING}

None

\section{REFERENCES}

1.Poder Legislativo. Decreto de Ley 19.172. Marihuana y sus derivados. Control y regulación del estado de la importación, producción, adquisición, almacenamiento, comercialización y distribución. [Internet] Montevideo, Uruguay. (2013). URL: https://legislativo.parlamento.gub. uy/temporales/leytemp3972264.htm

2. IRCCA. Mercado regulado del cannabis Montevideo2018 [cited 2018 05/08/18]. URL: https://www.ircca.gub.uy

3. Junta Nacional de Drogas. VI Encuesta en hogares sobre consumo de drogas - 2016. [Internet] Montevideo: Junta Nacional de Drogas; 2016. URL: https:/www.gub.uy/ junta-nacional-drogas/sites/junta-nacional-drogas/files/ documentos/publicaciones/201609_VI_encuesta_hogares OUD_ultima_rev.pdf the survey presents data for a population aged 35 to 44 years. It is therefore possible that exposure to cannabis could have a slight influence on the onset of periodontitis at an earlier age.

The main limitations of this study were the difficulty to access a larger sample, and the calculation of the response rate. However, among the advantages of this peculiarity is the fact that the sample consisted of recreational cannabis users who were officially registered at clubs. The fact that periodontitis was evaluated through self-reporting may also be considered a limitation, even though self-reporting is currently widely validated, despite the possibility of memory bias ${ }^{30}$.

To conclude, this study showed that among young peoplewhoaremembers of cannabis clubsinUruguay, the prevalence of self-reported periodontitis can be considered high compared to available data for the general population with similar sociodemographic and behavioral conditions. This suggests that smoking cannabis could have a potential detrimental effect on oral health status. This exploratory study provides a basis for further research using larger samples with the aim of evaluating how cannabis smoking affects the prevalence and progression (by means of longitudinal studies) of periodontitis in users who are members of cannabis clubs.

\section{CORRESPONDENCE}

Dra. Magdalena Mayol.

Las Heras 1925, Montevideo, Uruguay.

magdalenamayol@odon.edu.uy
4. Oficina de las Naciones Unidas contra la Droga y el Delito, Informe Mundial sobre las Drogas. 2017(S.17.XI.6). URL: https://www.unodc.org/wdr2017/field/WDR_Booklet1_ Exsum_Spanish.pdf

5. Murakami S, Mealey BL, Mariotti A, Chapple ILC. Dental plaque-induced gingival conditions. J Clin Periodontol. 2018;45 Suppl 20:S17-S27.

6. Dye BA. Global periodontal disease epidemiology. Periodontol 2000. 2012;58:10-25.

7. Kassebaum NJ, Bernabe E, Dahiya M, Bhandari B et al. Global burden of severe periodontitis in 1990-2010: a systematic review and meta-regression. J Dent Res. 2014;93:1045-1053. 
8. Papapanou PN. Periodontal diseases: epidemiology. Ann Periodontol. 1996;1:1-36.

9. Eke PI. Public health implications of periodontal infections in adults: conference proceedings. J Public Health Dent. 2005; 65:56-65.

10. Slade GD. Interim Analysis of Validity of Periodontitis Screening Questions in the Australian Population. J Periodontol. 2007;78 Suppl 7S:1463-1470.

11. Eke PI, Genco RJ. CDC Periodontal Disease Surveillance Project: Background, Objectives, and Progress Report. J Periodontol. 2007;78 Suppl 7S:1366-1371.

12. Eke PI, Dye B. Assessment of self-report measures for predicting population prevalence of periodontitis. $\mathrm{J}$ Periodontol. 2009;80:1371-1379.

13. Cyrino RM, Miranda Cota LO, Pereira Lages EJ, Bastos Lages EM et al. Evaluation of self-reported measures for prediction of periodontitis in a sample of Brazilians. J Periodontol. 2011;82:1693-1704.

14. Carra MC, Gueguen A, Thomas F, Pannier B et al. Self-report assessment of severe periodontitis: Periodontal screening score development. J Clin Periodontol. 2018;45:818-831.

15. Montero E, La Rosa M, Montanya E, Calle-Pascual AL et al. Validation of self-reported measures of periodontitis in a Spanish Population. J Periodontal Res. 2020;55:400-409.

16. Saka-Herran C, Jane-Salas E, Gonzalez-Navarro B, EstrugoDevesa A et al. Validity of a self-reported questionnaire for periodontitis in Spanish population. J Periodontol 2020. doi: 10.1002/JPER.19-0604. Epub ahead of print. PMID: 31984491 .

17. Verhulst MJL, Teeuw WJ, Bizzarro S, Muris J et al. A rapid, non-invasive tool for periodontitis screening in a medical care setting. BMC Oral Health. 2019;19:87. doi: 10.1186/ s12903-019-0784-7.

18. Abbood HM, Hinz J, Cherukara G, Macfarlane TV. Validity of Self-Reported Periodontal Disease: A Systematic Review and Meta-Analysis. J Periodontol. 2016;87:1474-1483.

19. Shariff JA, Ahluwalia KP, Papapanou PN. Relationship Between Frequent Recreational Cannabis (Marijuana and Hashish) Use and Periodontitis in Adults in the United States: National Health and Nutrition Examination Survey 2011 to 2012. J Periodontol. 2017;88:273-280.
20. Ortiz AP, Gonzalez D, Ramos J, Munoz C. Association of marijuana use with oral HPV infection and periodontitis among Hispanic adults: Implications for oral cancer prevention. J Periodontol. 2018;89:540-548.

21. Reddy S, Kaul S, Agrawal C, Prasad MG et al. Periodontal Status amongst Substance Abusers in Indian Population. ISRN Dent. 2012;2012:460856. doi: 10.5402/2012/460856

22. Meier MH, Caspi A, Cerda M, Hancox RJ et al. Associations Between Cannabis Use and Physical Health Problems in Early Midlife: A Longitudinal Comparison of Persistent Cannabis vs Tobacco Users. JAMA Psychiatry. 2016;73:731-740.

23. Mayol M, Andrade E, Perez Rivoir S, Bueno Rossy LA et al. Periodontal status in cannabis smokers. A systematic review. J Int Acad Periodontol. 2021;23:150-166.

24. Susin C, Dalla Vecchia CF, Oppermann RV, Haugejorden $\mathrm{O}$ et al. Periodontal attachment loss in an urban population of Brazilian adults: effect of demographic, behavioral, and environmental risk indicators. J Periodontol. 2004;75:10331341.

25. Eke PI, Dye BA, Wei L, Slade GD et al. Self-reported measures for surveillance of periodontitis. J Dent Res. 2013;92:1041-1047.

26. Bobes J, Bascarán MT, González MP, Sáiz PA. Epidemiología del uso/abuso de cannabis. Adicciones 2000;12:31-40.URL: https://www.researchgate.net/ publication/304203645_Epidemiologia_del_usoabuso_de_ cannabis

27. Pacula RL, Jacobson M, Maksabedian EJ. In the weeds: a baseline view of cannabis use among legalizing states and their neighbours. Addiction. 2016;111:973-980.

28. Junta Nacional de Drogas. Montevideo, IV Encuesta en hogares sobre consumo de drogas. URL:https://www. gub.uy/junta-nacional-drogas/sites/junta-nacional-drogas/ files/2018-01/OUD_4ta_encuesta_drogas_Uruguay_ hogares_2006.pdf

29. Lorenzo SM, Alvarez R, Andrade E, Piccardo V et al.. Cad Saude Publica. 2015;31:2425-2436.

30. Van den Bergh O, Walentynowicz M. Accuracy and bias in retrospective symptom reporting. Curr Opin Psychiatry. 2016;29:302-308. 